den befallenen Bestande her in einer Umgebung von mindestens $100 \mathrm{~m}$ im Umkreis ausbreiten kann.

Im Juni desselben Jahres besichtigte ich in
Kuopio die mir bekannten I. parviflora. Bestände in den Höfen an der Strasse Koljonniemenkatu, aber von dem Pilze bemerkte ich keine Spur.

\title{
Aecidium-ruostelöytöjä.
}

\section{Aarre Rauhala}

\section{Aecidium ligulariaen uusia itäkarjalaisia} löytöpaikkoja.

Helsingin Yliopiston kasvitieteellisen museon fanerogaamikokoelmista olen löytänyt Aecidium ligulariae Thüm.ruostetta seuraavista Itä-Karjalasta kerätyistä Ligularia sibirica (L.) Cass. -näytteistä:

Kon. Uunitsa (Unitza). 4. VIII, 1896. B. Poppius.

" Munjärvi. Letolla Motorinon tien alkupään luona. 3. VII. 1942. R. Tuomikoski.

, Munjärven Lahti. Korpimainen suo. 11. VII. 1942. N. Söyrinki.

, Jänkäjärvi. Kylästä n. $2 \mathrm{~km}$ etelään, letto. 10. VII. 1942. R. Kalliola \& J. Soveri.

Kpor. Suma. 1843. F. Nylander.

Liron (1908: Uredineae Fennicae - Finlands rostsvampar, s. 570) mukaan on tätä ruostetta löydetty Itä-Fennoskandiasta vain kolmesta paikasta: Kon. Tiudie. 10. VII. 1863. Th. Simming. (Tämän tiedon kanssa yhtäpitävä näyte löytyi museon fanerogaamiherbaariosta). - Kpoc. Onnanjoki. 12. VIII. 1896. J. I. Liro. (Tätä löytöä ei ole voitu tarkasti oheiselle kartalle sijoittaa). Kpor. Tamitsa, lähellä Valkean Meren rannalla sijaitsevaa Onegan kaupunkia. 26. VII. 1899. J. I. Liro. (Tämä löytöpaikka on varsinaisesti jo Kpor-maakunnan itärajan ulkopuolella.)

On merkillepantavaa, että vaikka museossa on pohjoisemmista maakunnista $L v$ ja $L p$ myös melkoisesti Ligulariasta näytteitä, näistä ei ole löytynyt tautia lainkaan, mikä viitannee siihen, että sieni esiintyy noilla alueilla - mikäli sitä siellä ollenkaan on - harvinaisempana kuin etelässä. Joka tapauksessa on selvää, että sienen levinneisyyttä Itä-Fennoskandiassa ei vielä lähimainkaan täydellisesti tunneta.

\section{Aecidium barbareae DC. Suomesta.}

Helsingin Yliopiston kasvitieteellisen museon tarkemmin määrittämättömien ruostesienten joukosta olen todennut kaksi Aecidium barbareae DC. -näytettä, molemmat Barbarea vulgarikselta. Ne on ottanut pankinjohtaja W. Nyberg Kauniaisista (U), toisen 26. V. 1939 prof. Nybergin huvilalta ja toisen 1. VI. 1940 rautatieaseman luota.

Lajia ei ole ennen ilmoitettu Suomesta.

\section{Aecidium-Funde.}

\section{Neue Fundorte des Aecidium ligulariae Thüm. in Ostkarelien.}

Der Verfasser hat bei den Ligularia sibirica (L.) Cass.-Proben des Phanerogamherbariums der Universität Helsinki neue Standorte des Rostpilzes Aecidium ligulariae Thüm. in Ostkarelien in den Provinzen Kon und Kpor gefunden (siehe Karte).
2. Aecidium barbareae DC. in Finnland

Der Verfasser hat in der Pilzsammlung des Botanischen Museums der Universität Helsinki zwei Proben von einem auf Barbarea vulgaris $\mathrm{RBr}$. lebenden Rostpilze angetroffen, die von dem Mykologen W. Nyberg in Kauniainen (N) in den Jahren 1939 und 1940 gesammelt worden sind. Die Proben hören zu der Art Aecidium barbareae DC, welche für Finnland neu ist.

\section{Über ausgiebige Perithecienbildung bei Erysiphe Martii Lév. auf Melilotus albus Med. und bei Erysiphe verbasci (Jacz.) Blumer auf. Verbascum nigrum $\mathbf{L}$.}

\section{Aarre Rauhala}

Am 5. XI. 1950 stellte ich an den Pflanzen eines ausgedehnten und schon ziemlich alten $M e-$ illotus albus Med.-Bestandes in Hietaniemi im. Westen von Helsinki ein reichliches Auftreten des Mehltaupilzes Erysiphe Martii Lév. im Fruchtkörperstadium fest. S. Blumer (Die 